\title{
What Drives the Volatility of Firm Level Productivity in China?
}

\author{
Xubei Luo ${ }^{1}$ \\ The World Bank, USA \\ xluo@worldbank.org \\ Nong Zhu \\ INRS-UCS, University of Quebec, Canada \\ nong.zhu@ucs.inrs.ca
}

Received: 17 April 2015 / Revised: 29 June 2015 / Accepted: 15 July 2015 / Published online: 16 November 2015

\begin{abstract}
The enterprise reforms of the 1990s profoundly changed the structure of the economy in China. Using a firm-level dataset collected annually during the period of 1998-2007, this paper examines the variation of productivity volatility across firms of different characteristics as well as its evolution over time, and investigates the sources of productivity volatility at the firm level. The results suggest that in general, productivity volatility at the firm level declined over time in China. Large firms, old firms, foreign firms, and firms located in the coastal provinces are less volatile. Firm size and location are the two major factors that drive changes in productivity volatility - one in a positive way and one in a negative way. While the gaps of volatility between smaller firms and larger firms declined, the gaps between firms located in the coastal provinces and inland provinces increased.
\end{abstract}

JEL classification: C21; D21; E23.

Key words: Enterprise Reform; Productivity; Volatility; China.

\section{INTRODUCTION}

The Chinese economy has witnessed impressive development since the economic reforms of the late 1970s. Over the past three decades, there have been important reforms and transformations in the enterprise sector: expansion of Township and Village-ship Enterprises (TVEs), privatization of small and medium state-owned enterprises, modernization of large state-owned enterprises, as well as development of foreign enterprises. Since the late 1990s, the economy continued rapid and steady growth even during challenging periods such as the Asian financial crisis and the global dot.com bubble. The government further deepened the reforms after its accession to the World Trade Organization.

With the deepening of market economy, the share of the state-owned and collective enterprises declined. Expansion and contraction, as well as establishment and closure, of firms became

1 Corresponding author: Xubei Luo, The World Bank, 1818 H Street N.W., Washington, D.C. 20433, USA, Phone +1 202.458.1157, Fax+1 202.522.0056, Email: xluo@worldbank.org, Web: http://www.worldbank.org/wdr2014. 
a common phenomenon, with resources shifting to potentially more productive areas. The level and volatility of firm productivity have become increasingly important aspects of the micro performance of the economy. While many studies of the Chinese economy focus on investigating the factors that condition the aggregate productivity and the inequality between coastal and inland regions as well as rural and urban areas, this paper takes a closer look at the firm level output growth and examines the drivers of its volatility over time. The volatility of productivity reflects responses of firms to idiosyncratic shocks and frictions in product, factor and credit markets. The objectives of this paper include (i) analyze the evolution of productivity volatility at the firm level over time, (ii) identify the determinants of productivity volatility, and (iii) examine the sources of change in productivity volatility. The literature on firms' economic performance is abundant. However, most previous studies focus on the level of productivity. To our knowledge, the present paper is the first analysis of the volatility of productivity in China. ${ }^{2}$

This study is based on a firm-level dataset collected annually by the National Bureau of Statistics of China. This dataset covers about 300 thousands industrial firms in 1998-2007. ${ }^{3}$ This paper follows the methodology developed in Comin and Philippon $(2005 ; 2007)$ to measure firm productivity volatility as the standard deviation of the annual growth rate of output per worker.

Our hypotheses are as follows. First, productivity is determined both by the intrinsic endowment of firm, mainly represented by size, age, ownership, etc., and the external environment measured by geographic location. Second, the change in firm characteristics and that the change in the effect of firm characteristics on productivity both contribute to the difference in firm economic performance, and thus the change in productivity volatility over time.

Our empirical work is composed of three parts. First, the paper compares the productivity of three groups of firms - those that survived the entire 10 year period of 1998-2007, those that survived any consecutive 5 years, and all firms in the sample - and focuses on the second group for the analysis of evolution of productivity volatility over time.

Second, it describes the changes in the composition of different types of firms (size, age, ownership, and location) and examines the roles that these different characteristics, along with investment in long-term and intangible assets, innovation, export intensity, and insurance and pension payments, play in the determination of the level of firm productivity volatility and its evolution over time.

Third, it investigates the effect of these firm characteristics in the changes in firm productivity volatility. Applying of the method of Oaxaca decomposition as developed in Smith and Welch (1989), it decomposes their effect into (i) main effect that occurs because of change in firm characteristics and (ii) year effect because of a change in return to these characteristics.

\section{ENTERPRISE REFORMS}

Before the enterprise reforms in the 1990s, state-owned and collective enterprises played a dominant role in the economy. The state-owned enterprises (SOEs) were not independent entities - they were subordinates to the government. As in other planned economies, production and market were separated. As to the provision of social protection, the roles of the government and the enterprises were blurry. In many circumstances, large state-owned enterprises also had hospitals and elementary and middle schools, and functioned to a certain extent as a relatively small independent community. Many urban workers worked for only one firm in their entire working life. Job mobility was very low and workers depended on the enterprises they work for in multiple aspects, from in kind benefits to health care, children's education, and to old-age pension.

We use output per worker to measure productivity

In this paper, we use "firms" as shorthand for "industrial firms". 
Social stability is always a priority of Chinese government. Laying off employees was generally prohibited, even in the enterprises in deficit. In contrast, the "soft-budget" constraint allowed unproductive firms to rely on financial support from the government, which severely limited enterprises' motivation to get out of the difficult situation by reallocating resources to improve efficiency. Many SOEs were therefore in deficit and suffered from a relatively low efficiency. In the central planning era, virtually all labor was employed. Many loss-making SOEs were kept alive and redundant workers employed with their guaranteed jobs - "iron rice bowl" (or "tie fan wan") - and social entitlements. ${ }^{4}$

The reforms of the 1990s fundamentally restructured the enterprise sector. Firm closures or mergers and workers laid-off from secure and lifetime jobs, which were rare for SOEs in the past, became a crude reality. Millions of workers found themselves unemployed and open unemployment emerged in urban areas. A large share of state-owned or collective enterprises were restructured to corporate-owned or private-owned. At the same time, private enterprises, foreign enterprises, and Hong Kong SAR (Special Administrative Region), China, Macao SAR, China, and Taiwan, China, owned enterprises rapidly developed, which created a large share of employment opportunities. In 1999, almost two-thirds of the enterprises were state-owned enterprises or collective enterprises; in 2007, the ratio declined to less than one-tenth, according to our firm level dataset. This is broadly consistent with the trend indicated in the statistics of the National Statistical Yearbooks: in 2001, the share of employment in SOEs was $60.9 \%$ of the urban labor; it decreased to $23.7 \%$ in 2005 , and $18.7 \%$ in 2011 (see Figure 1). ${ }^{5}$ This transformation of the enterprise sector provided jobs of a different nature to a large share of the labor force (World Bank, 2007).

Figure 1.

The number of employed persons by enterprise ownership in Urban China (2001-2011)

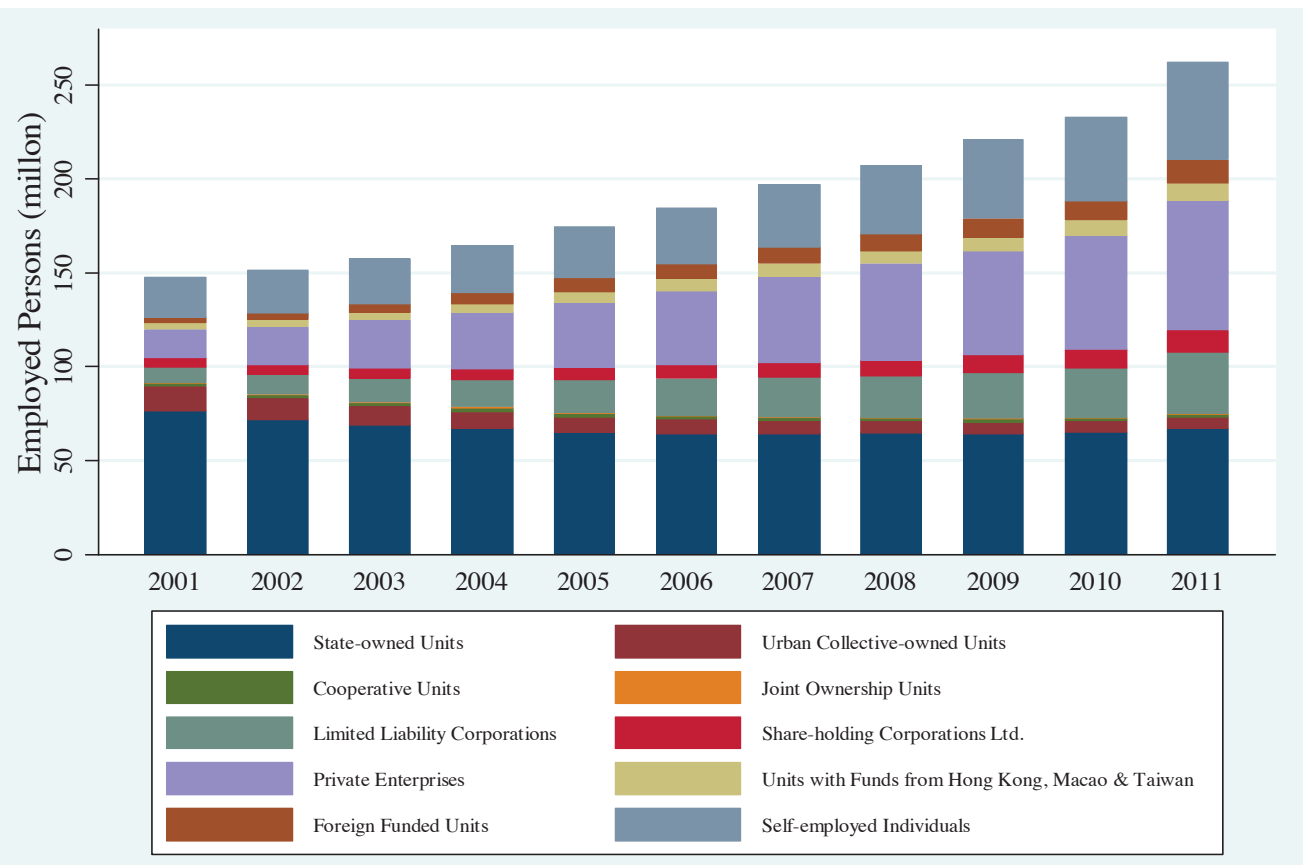

Sources: China Statistical Yearbooks, 2002-2012.

\footnotetext{
4 See for instant Bari (1997); de Beer and Rocca, 1997; Putterman, 1992; etc.

5 Figure 1 is a descriptive analysis using aggregated data that come from statistical yearbooks and covers the period 2001-2011. The empirical analysis in Sections 3 and 4 is based on a firm-level dataset collected annually in 1998-2007.
} 
With the restructuring of the enterprise sector, firm turnovers and job churnings became normal phenomena. Creative destruction accounted for a higher share of the increase in productivity. Workers no longer tied to one firm. The risk of being laid off by one firm was separated from the risk of being unemployed. Spurred by the rapid development in the coastal provinces or urban areas, millions of migrant workers left their hometowns in inland or rural areas to pursue better job opportunities. The supply of inexpensive labor served as a strong "push force" to further stimulate the economic growth and attracted more domestic private investment and foreign direct investment in the coastal urban. The spillover effects of foreign direct investment on domestic firms vary. Wei and Liu (2006) indicated that there are positive inter-industry productivity spillovers from R\&D and exports, and positive intra- and inter-industry productivity spillovers from foreign presence to domestic firms within regions. Du et al. (2011) elaborated on the different channels and mixed effects through forward linkages and backward linkages, and argued that the positive spillover is insignificant for horizontally integrated firms. Regardless, the increase in private investment and non-state-owned firms provided the basis for the deepening of the enterprise reforms.

With the development of the market economy, the volatility of firm level productivity becomes a crucial aspect of the micro performance of an economy. It reflects responses of firms to idiosyncratic shocks and frictions in product, factor and credit markets. Firm level volatility often links to their investment patterns, their access to external finance, as well as the regulation reforms. The volatility of the entire private sector reflects the joint forces of firm entry and exit and the volatility of the individual firms in the market.

\section{EVOLUTION OF PRODUCTIVITY VOLATILITY}

Firm level productivity volatility is an important aspect of whole economic development. In previous studies, volatility is measured in different ways. In Loayza and Servén (2010), macroeconomic volatility is represented by the standard deviation of the output gap, obtained as the difference between the actual real RDP per capita and trend real GDP per capita. Trend output is estimated using the band-pass filter of Baxter and King (1999). In Hausmann and Gavin (1996), macroeconomic volatility is defined as the standard deviation of the level of GDP per capita. In Breen and García-Peñalosa (2005), output volatility is defined as the standard deviation of the annual growth rate of real per capita GDP.

In this study, we follow the methodology developed in Comin and Philippon (2005). They used aggregate data from the National Income and Product Accounts (NIPAs), and firm level data from COMPUSTAT (a database of financial, statistical and market information on active and inactive global companies throughout the world) and the Center for Research in Security Prices (CRSP), which is composed of time series that vary from 1955 to 2000. For each firm $i$ at time $t$, they computed the volatility as the standard deviation of the annual growth rate of sales during each ten-years:

$$
\sigma_{i, t}=\sqrt{\frac{1}{10} \sum_{\tau=-4}^{+5}\left(\gamma_{t+\tau, i}-\bar{\gamma}_{t, i}\right)^{2}}
$$

Our study is based on a firm-level dataset collected annually by the National Bureau of Statistics of China. This dataset covers about 300 thousands firms in 1998-2007, but the length is only 10 years and only a subset of approximately 32000 firms are available for the entire 10 year period. Thus we adapt to their approach and use two methods to measure productivity volatility.

For the firms that survived the entire 10 year period (1998-2007), we define the productivity volatility as the standard deviation of the annual growth rate of total output per worker during 1999-2007: 


$$
\sigma_{i}=\sqrt{\frac{1}{9} \sum_{k=1999}^{2007}\left(\gamma_{i, k}-\bar{\gamma}_{i}\right)^{2}}
$$

where $\gamma_{i, k}$ is the annual growth rate of output per worker for firm $i$ at year $k$, and $\bar{\gamma}_{i}$ the average growth rate between 1999 and 2007.

However, this measure only allows us to perform cross-section analysis. To study the evolution of volatility over time, we use an alternative method shortening the time span to five years and focus on the firms that survived at least 5 years. We compute the productivity volatility as the standard deviation of the annual growth rate of total output per worker during each 5 consecutive years:

$$
\sigma_{i, t}=\sqrt{\frac{1}{5} \sum_{k=t-2}^{t+2}\left(\gamma_{i, k}-\bar{\gamma}_{i}\right)^{2}}
$$

where $\gamma_{i, k}$ is the annual growth rate at year $k$ for firm $i$, and $\bar{\gamma}_{i}$ the average growth rate between $t-2$ and $t+2 ; t$ varies from 2001 to 2005 . This measure is similar to that of Comin and Philippon (2005). But it allows us to expand the sample to a panel and analyze the change of productivity volatility over time.

Figure 2 presents the relationship between the level and volatility of productivity for the firms that survived the entire 10 year period 1998-2007. It shows that, as the level of productivity increases, volatility tends to decline. In other words, overall, there is some negative association between the level of productivity and the volatility of productivity.

\section{Figure 2.}

Relationship between the level and volatility of productivity

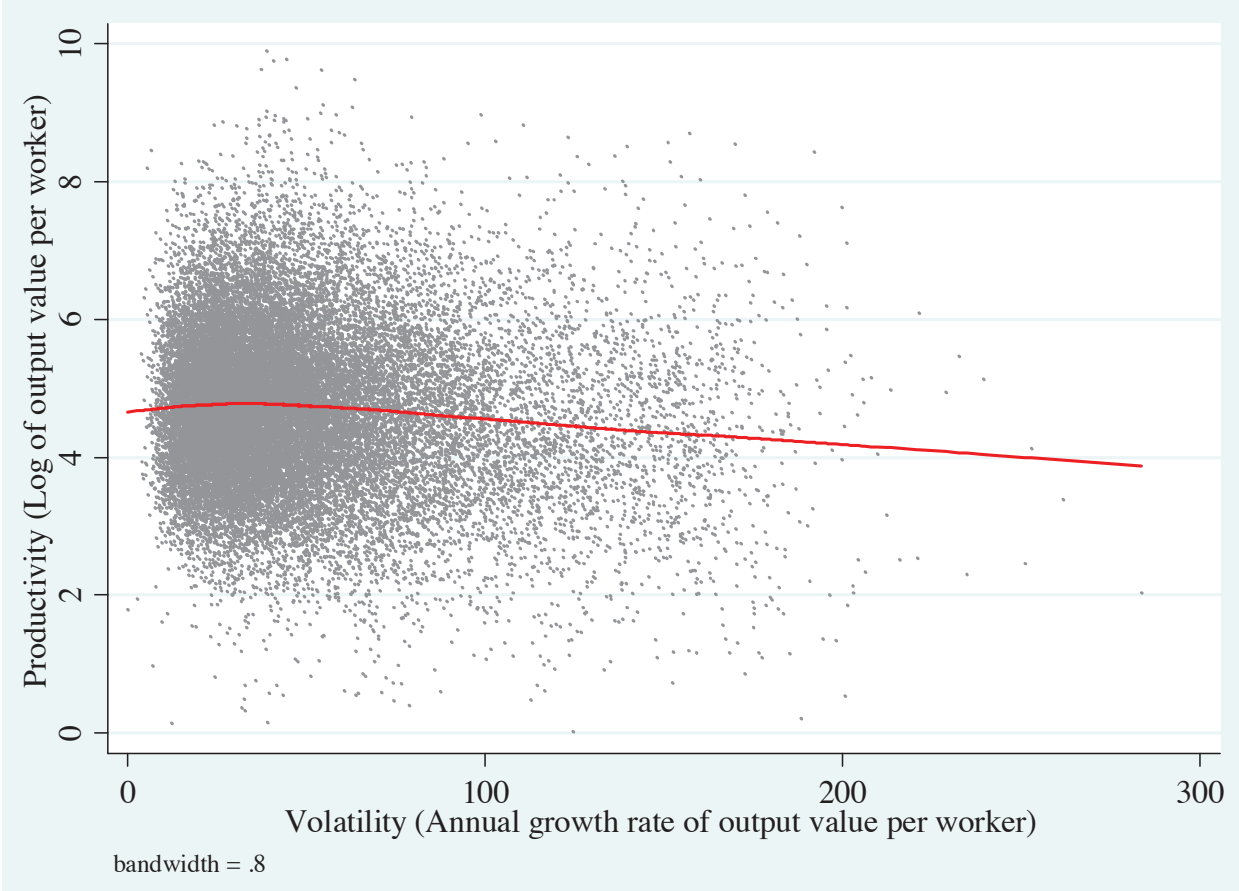

Note: The firms in the sample are those that survived for the entire 10 year period.

Table 1 shows that the average magnitudes of the volatility in the annual growth rate of output per capita of the firms that survived the entire 10 year period and those that survived at least 5 years. It shows that overall volatility declined over time. This downward trend of productivity volatility also applies to most firms of different characteristics, such as size, age, ownership, and location (in inland and coastal regions). 
Table 1.

Evolution of firm level productivity volatility

\begin{tabular}{|c|c|c|c|c|c|c|c|}
\hline & \multirow[b]{2}{*}{$\begin{array}{l}\text { Firms } \\
\text { survived } \\
\text { the entire } \\
10 \text { year } \\
\text { period }\end{array}$} & \multicolumn{6}{|c|}{ Firms survived for at least five consecutive years $[t-2, t+2]$} \\
\hline & & 2001 & 2002 & 2003 & 2004 & 2005 & $\begin{array}{c}\text { Change in } \\
\text { volatility } \\
\text { between } \\
2001 \text { and } \\
2005\end{array}$ \\
\hline Total & 48.2 & 43.71 & 42.69 & 42.41 & 42.54 & 42.76 & -0.95 \\
\hline \multicolumn{8}{|l|}{ Firm size } \\
\hline Less than 50 & 56.0 & 53.53 & 52.10 & 51.40 & 52.32 & 51.43 & -2.11 \\
\hline $50-100$ & 49.2 & 46.90 & 45.06 & 44.65 & 45.04 & 45.01 & -1.89 \\
\hline $100-500$ & 47.8 & 43.07 & 42.05 & 41.74 & 41.64 & 42.04 & -1.03 \\
\hline More than 500 & 44.3 & 37.16 & 37.45 & 37.25 & 36.04 & 36.65 & -0.51 \\
\hline \multicolumn{8}{|l|}{ Firm's age } \\
\hline Less than 5 years & 49.3 & 48.89 & 47.25 & 46.58 & 48.39 & 48.86 & -0.03 \\
\hline $6-10$ years & 47.9 & 43.50 & 42.27 & 41.90 & 42.12 & 43.13 & -0.36 \\
\hline $11-20$ years & 47.2 & 42.63 & 41.65 & 41.48 & 40.63 & 39.94 & -2.69 \\
\hline More than 20 years & 47.1 & 41.69 & 41.44 & 41.29 & 39.84 & 39.36 & -2.33 \\
\hline \multicolumn{8}{|l|}{ Main part of paid-in capital } \\
\hline State capital & 49.3 & 44.48 & 44.65 & 44.12 & 43.56 & 42.12 & -2.36 \\
\hline Collective capital & 50.0 & 44.10 & 42.54 & 43.68 & 42.84 & 42.86 & -1.25 \\
\hline Corporate capital & 48.9 & 44.09 & 43.52 & 43.76 & 44.10 & 45.10 & 1.00 \\
\hline Personal capital & 48.9 & 43.15 & 42.42 & 42.13 & 42.92 & 43.07 & -0.08 \\
\hline $\begin{array}{l}\text { Hong Kong SAR, China, } \\
\text { Macao SAR, China, and } \\
\text { Taiwan, China, capital }\end{array}$ & 48.0 & 44.93 & 42.13 & 40.82 & 40.36 & 40.72 & -4.21 \\
\hline Foreign capital & 45.3 & 40.01 & 38.72 & 38.26 & 38.56 & 38.87 & -1.15 \\
\hline \multicolumn{8}{|l|}{ Region } \\
\hline Inland province & 51.3 & 45.43 & 44.49 & 44.59 & 45.87 & 46.92 & 1.49 \\
\hline Coastal province & 46.6 & 42.66 & 41.79 & 41.45 & 41.01 & 40.88 & -1.79 \\
\hline Number of observations & 29483 & 49375 & 46045 & 51929 & 68965 & 78330 & \\
\hline
\end{tabular}

Note: The volatility is measured as the standard deviation of annual growth output per worker at the firm level. The output value in each year is adjusted to 1998 price using Producer Price Index for Manufactured Goods provided by China Statistical Yearbooks.

Using Kernel density, we examine the distribution of productivity volatility by firm size. Consistent with the literature, small firms are more volatile than large firms. Figure 3 shows that, as firm size increases, both the level and variance of productivity volatility decrease. Similarly, we observe that young firms are more volatile than old firms, and firms in the inland region are more volatile than firms in the coastal region. Firms with foreign capital as the main part of paidin capital are the least volatile. During the period of study, productivity volatility declined in the coastal region, but increased in the inland region. 
Figure 3.

Kernel distribution of productivity volatility

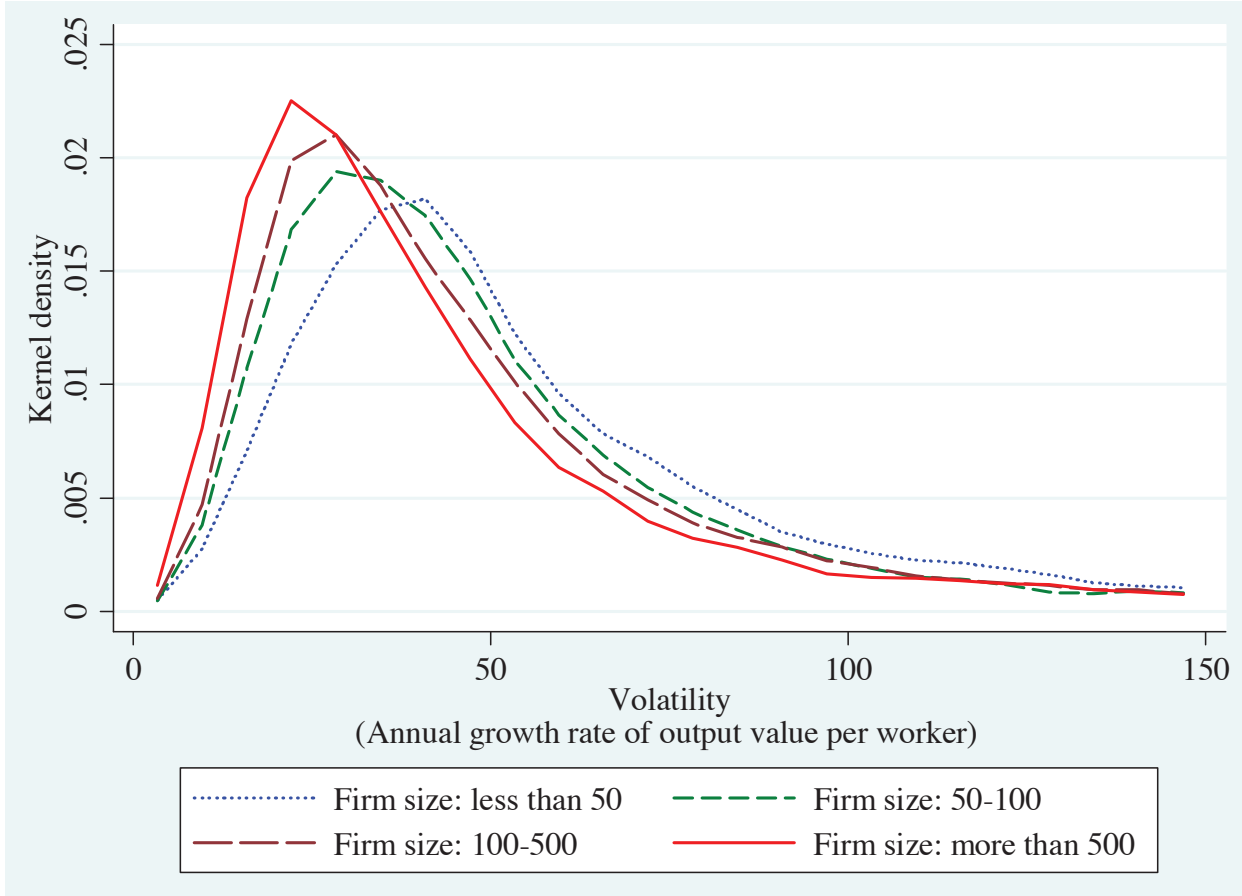

Note: The firms in the sample are those that survived for the entire 10 year period.

Two interesting findings emerge when we examine the role of firm characteristics in the changes in productivity volatility over time: first, the marginal impact of firm size on volatility is converging - large firms are less volatile compared with small firms, but over time, the gap of volatility between large firms and small firms tend to decline. Second, the marginal impact of firm age on volatility is diverging - young firms are more volatile than old firms, and over time, the gap of volatility between young firms and old firms tends to increase. This might indicate, on the one hand, that the government's support to the SMEs has been taking effect; and on the other hand, that young firms are more likely to experience experimentation and adjustment in the market and they are more volatile when competition is higher.

As mentioned above, we select only the firms that survived at least 5 years in the analysis of the evolution of volatility. The firms that disappeared before 2002, those that were established after 2003, and some others whose data are not available are excluded from our analysis. One might raise the following question: how different are the selected firms compared with all firms in the population? For example, are the selected firms more or less productive than others? We compare the productivity of the selected firms with that of all the firms in the sample (Table 2). The statistics show, in general, the difference in productivity between selected firms and all firms in the sample is significant. As expected, this difference is negative in a significant manner for several sub-groups, implying that the selected firms are likely those with higher productivity. The following sections focus on the firms that survived for at least five consecutive years. ${ }^{6}$ 
Table 2.

Average output per worker

\begin{tabular}{|c|c|c|c|c|c|c|c|c|}
\hline \multirow[b]{3}{*}{ Total } & \multicolumn{4}{|c|}{2001} & \multicolumn{4}{|c|}{2005} \\
\hline & \multirow{2}{*}{$\begin{array}{c}\begin{array}{c}\text { All } \\
\text { firms }\end{array} \\
218.4\end{array}$} & \multirow{2}{*}{$\begin{array}{c}\begin{array}{c}\text { Selected } \\
\text { firms }\end{array} \\
227.3\end{array}$} & \multicolumn{2}{|c|}{ Difference } & \multirow{2}{*}{$\begin{array}{c}\begin{array}{c}\text { All } \\
\text { firms }\end{array} \\
346.5\end{array}$} & \multirow{2}{*}{$\begin{array}{c}\begin{array}{c}\text { Selected } \\
\text { firms }\end{array} \\
367.1\end{array}$} & \multicolumn{2}{|c|}{ Difference } \\
\hline & & & $-8.9^{* * *}$ & $(-2.93)$ & & & $-20.5^{* * *}$ & $(-4.86)$ \\
\hline \multicolumn{9}{|l|}{ Firm size } \\
\hline Less than 50 & 357.9 & 402.9 & $-44.9^{* * *}$ & $(-3.05)$ & 517.9 & 708.8 & $-190.9^{* * *}$ & $(-10.42)$ \\
\hline $50-100$ & 206.8 & 281.8 & $-75.0^{* * *}$ & $(-15.33)$ & 301.6 & 391.2 & $-89.6^{* * *}$ & $(-14.85)$ \\
\hline $100-500$ & 153.4 & 191.2 & $-37.7^{* * *}$ & $(-12.94)$ & 247.1 & 300.2 & $-53.1^{* * *}$ & $(-12.08)$ \\
\hline More than 500 & 153.1 & 178.9 & $-25.8^{* * *}$ & $(-5.59)$ & 282.7 & 321.4 & $-38.7^{* * *}$ & $(-4.41)$ \\
\hline \multicolumn{9}{|l|}{ Firm's age } \\
\hline Less than 5 years & 263.9 & 287.7 & $-23.9^{* * *}$ & $(-2.86)$ & 371.4 & 389.8 & $-18.4^{* *}$ & $(-2.19)$ \\
\hline $6-10$ years & 243.7 & 305.9 & $-62.2^{* * *}$ & $(-10.26)$ & 347.5 & 418.5 & $-71.0^{* * *}$ & $(-6.97)$ \\
\hline $11-20$ years & 185.0 & 213.5 & $-28.5^{* * *}$ & $(-5.27)$ & 298.6 & 362.1 & $-63.6^{* * *}$ & $(-9.86)$ \\
\hline More than 20 years & 100.8 & 112.6 & $-11.8^{* * *}$ & $(-5.11)$ & 194.0 & 227.0 & $-32.9^{* * *}$ & $(-5.39)$ \\
\hline \multicolumn{9}{|l|}{ Main part of paid-in capital } \\
\hline State capital & 128.5 & 120.0 & 8.5 & $(1.40)$ & 269.3 & 320.1 & $-50.8^{* *}$ & $(-2.18)$ \\
\hline Collective capital & 226.6 & 223.7 & 2.9 & $(0.39)$ & 360.5 & 370.1 & -9.6 & $(-0.62)$ \\
\hline Corporate capital & 251.2 & 249.4 & 1.7 & $(0.17)$ & 376.9 & 401.0 & $-24.1^{* * *}$ & $(-2.58)$ \\
\hline Personal capital & 228.9 & 222.1 & 6.8 & $(1.11)$ & 329.7 & 332.2 & -2.5 & $(-0.56)$ \\
\hline $\begin{array}{l}\text { Hong Kong SAR, China, } \\
\text { Macao SAR, China, and } \\
\text { Taiwan, China, capital }\end{array}$ & 266.3 & 288.1 & -21.8 & $(-1.35)$ & 312.3 & 349.0 & $-36.7^{* * *}$ & $(-2.59)$ \\
\hline Foreign capital & 375.7 & 467.4 & $-91.6^{* * *}$ & $(-3.71)$ & 469.2 & 602.6 & $-133.4^{* * *}$ & $(-4.96)$ \\
\hline \multicolumn{9}{|l|}{ Region } \\
\hline Inland province & 147.9 & 142.9 & 5.0 & $(1.41)$ & 303.6 & 286.9 & $16.6^{* * *}$ & $(2.87)$ \\
\hline Coastal province & 254.0 & 261.6 & $-7.6^{*}$ & $(-1.84)$ & 362.8 & 391.1 & $-28.3^{* * *}$ & $(-5.34)$ \\
\hline Number of observations & 117457 & 49375 & & & 192734 & 78330 & & \\
\hline
\end{tabular}

Note: t-statistics in parentheses. ${ }^{* * *}$ significant at $1 \% ;{ }^{* *}$ significant at $5 \% ;{ }^{*}$ significant at $10 \%$. The selected firms are those that survived at least 5 years.

\section{SOURCES OF CHANGE IN PRODUCTIVITY VOLATILITY}

The changes over time in aggregate productivity volatility can result mainly in two forces: first, the composition of firms of different characteristics; and second, the changes in the effect of firm characteristics on productivity volatility. In this section, we will examine these two driving forces using a development of Blinder-Oaxaca decomposition to analyze the change in productivity volatility for the firms that survived at least for five consecutive years during the period 2001 and 2005 (Blinder, 1973; Oaxaca, 1973; Smith and Welch, 1989; The World Bank, 2007). 
Mathematically, starting from two productivity volatility equations for each firm, one for 2001 and one for 2005:

$$
\begin{array}{ll}
y_{i}=\sum_{j=1}^{J} \beta_{j}^{01} x_{j, i}+\mu_{i}^{01} & \text { for } 2001 \\
y_{i}=\sum_{j=1}^{J} \beta_{j}^{05} x_{j, i}+\mu_{i}^{05} & \text { for } 2005
\end{array}
$$

where $y_{i}$ represents the productivity volatility of firm $i$; and $X_{i}=\left\{x_{j, i}\right\}_{j=1}^{J}$ are the independent variables, we estimate:

$$
\begin{array}{ll}
\log \hat{y}_{i}=\hat{\beta}^{01} X_{i} & \text { for } 2001 \\
\log \hat{y}_{i}=\hat{\beta}^{05} X_{i} & \text { for } 2005
\end{array}
$$

We can decompose the influence of various attributes into (i) main (characteristic or endowment) effects that occur because of changes in firm characteristics and (ii) year (price or coefficient) effects which are due to changes in return to the specific characteristics. This decomposition allows one to assess the sources of volatility variation during the period studied (2001-2005).

The change in productivity volatility during the period 2001-2005 can be decomposed as follows:

$$
\Delta y=\bar{y}_{05}-\bar{y}_{01}=\hat{\beta}^{01}\left(\bar{X}_{05}-\bar{X}_{01}\right)+\left(\hat{\beta}^{05}-\hat{\beta}^{01}\right) \bar{X}_{05}=\hat{\beta}^{01} \cdot \Delta \bar{X}+\Delta \hat{\beta} \cdot \bar{X}_{05}
$$

where $\bar{y}_{01}$ and $\bar{y}_{05}$ are logarithm of geometric mean volatility in 2001 and 2005, respectively. $\hat{\beta}^{01}\left(\bar{X}_{05}-\bar{X}_{01}\right)=\hat{\beta}^{01} \cdot \Delta \bar{X}$ denotes the main effect of the independent variables, that is, endowment or characteristic effects, and $\left(\hat{\beta}^{05}-\hat{\beta}^{01}\right) \bar{X}_{05}=\Delta \hat{\beta} \cdot \bar{X}_{05}$ the year effect, which represents changes in returns to specific characteristics.

In addition, with the estimation results, we can analyze the contribution of each independent variable to the change in volatility between 2001 and 2005. Let $X_{i}=\left.\left\{x_{j}\right\}\right|_{j=1} ^{J}$ stand for the vector of explanatory variables, and $\hat{\beta}=\left\{\hat{\beta}_{j}\right\}_{j=1}^{J}$ the vector of estimated coefficients. The decomposition of equation (8) can be written as follows:

$$
\Delta y=\bar{y}_{05}-\bar{y}_{01}=\sum_{j=1}^{J}\left(\hat{\beta}_{j}^{01}\left(\bar{x}_{j, 05}-\bar{x}_{j, 01}\right)+\left(\hat{\beta}_{j}^{05}-\hat{\beta}_{j}^{01}\right) \bar{x}_{j, 05}\right) .
$$

Factors that influenced productivity volatility are included in the equations (4) and (5). They consist of firm size and age; main part of paid-in capital, which is a proxy of firm ownership; ratio of long-term investment to total output value; ratio of intangible assets value to total output value; ratio of export delivery value to total output value; ratio of new product value to total output value; ratio of labor, unemployment insurance to total output value; ratio of medical and retirement insurance to total output value. We also introduce a dummy variable indicating coastal province.

Table 3 presents descriptive statistics for the 2001 and 2005 samples of firms that survived at least five consecutive years. Average productivity volatility declined from 2001 to $2005 .{ }^{7}$ During this period, the share of small and medium firms has increased, while that of large firms declined. The share of state-owned and collective firms experienced a significant decline from $47 \%$ to $18 \%$, while the share of firms financed by private capital has seen a sharp increase from $22 \%$ to $40 \%$. The share of export delivery value to sales total output value increased over time. The share of firms located in coastal provinces rose from $72 \%$ to $77 \%$.

\footnotetext{
7 As we removed some observations of which the information is incomplete or certain values are extreme, the difference in productivity volatility between 2001 and 2005 is slightly different from the results presented in Table 1.
} 
Table 3.

Description of the sample of firms that survived at least 5 years

\begin{tabular}{|c|c|c|c|}
\hline & $\begin{array}{c}2001 \\
\left(\bar{y}_{01} \text { and } \bar{X}_{01}\right)\end{array}$ & $\begin{array}{c}2005 \\
\left(\bar{y}_{05} \text { and } \bar{X}_{05}\right)\end{array}$ & $\begin{array}{l}\text { Difference } \\
(\Delta y \text { and } \Delta \bar{X})\end{array}$ \\
\hline Productivity volatility & 43.60 & 42.74 & -0.86 \\
\hline \multicolumn{4}{|l|}{ Firm size $(\%)$} \\
\hline Less than 50 workers & 10.68 & 10.95 & 0.27 \\
\hline 50-100 workers & 17.64 & 20.40 & 2.76 \\
\hline $100-500$ workers & 52.16 & 51.73 & -0.43 \\
\hline More than 500 workers & 19.51 & 16.92 & -2.59 \\
\hline \multicolumn{4}{|l|}{ Firm age $(\%)$} \\
\hline Less than 5 years & 16.93 & 19.86 & 2.93 \\
\hline $5-10$ years & 33.49 & 35.72 & 2.23 \\
\hline $10-20$ years & 20.43 & 29.17 & 8.74 \\
\hline More than 20 years & 28.95 & 15.25 & -13.7 \\
\hline \multicolumn{4}{|l|}{ Main part of paid-in capital (\%) } \\
\hline State capital & 26.46 & 9.60 & -16.86 \\
\hline Collective capital & 20.47 & 8.86 & -11.61 \\
\hline Corporate capital & 17.15 & 23.62 & 6.47 \\
\hline Private capital & 21.99 & 40.42 & 18.43 \\
\hline $\begin{array}{l}\text { Hong Kong SAR, China, Macao SAR, China, } \\
\text { and Taiwan, China, capital }\end{array}$ & 9.74 & 10.25 & 0.51 \\
\hline Foreign capital & 8.96 & 10.48 & 1.52 \\
\hline Ratio of long-term investment to output value (\%) & 4.53 & 3.12 & -1.41 \\
\hline Ratio of intangible assets to output value (\%) & 4.48 & 4.30 & -0.18 \\
\hline Ratio export delivery value to sales total output value (\%) & 18.17 & 21.54 & 3.37 \\
\hline Ratio of new product to output value (\%) & 3.17 & 4.31 & 1.14 \\
\hline Ratio of labor, unemployment insurance to output value $(\%)$ & 0.12 & 0.09 & -0.03 \\
\hline Ratio of medical and retirement insurance to output value $(\%)$ & 0.80 & 0.25 & -0.55 \\
\hline Coastal province $(\%)$ & 71.16 & 76.95 & 5.79 \\
\hline Number of observations & 49167 & 78186 & \\
\hline
\end{tabular}

Table 4 presents the results of productivity volatility, as in equations (4) and (5). A negative (positive) sign of the coefficient indicates the factor plays a role in reducing (enhancing) productivity volatility. The size of firms has a negative effect on productivity volatility (or, more directly, it means large firms are less volatile); however, the negative effect of the size of firms on volatility seems to weaken over time. This is consistent with the results that we observed in the previous section when we examine the sample of firms that survived the entire ten year period: large firms are less volatile compared with small firms, but over time, the gap of volatility between large firms and small firms tend to decline. The age of firms has a negative effect on volatility, and this effect has become stronger from 2001 to 2005. 
Table 4.

Determinants of productivity volatility

Dependent variable: Standard deviation of annual growth rate of output value per worker

\begin{tabular}{|c|c|c|c|}
\hline & $\begin{array}{l}2001 \\
\left(\hat{\beta}^{01}\right)\end{array}$ & $\begin{array}{l}2005 \\
\left(\hat{\beta}^{05}\right)\end{array}$ & $\begin{array}{l}\text { Difference } \\
\qquad(\Delta \hat{\beta})\end{array}$ \\
\hline \multicolumn{4}{|l|}{ Firm size (Reference: less than 50) } \\
\hline $50-100$ & $\begin{array}{l}-6.184^{* * *} \\
(-10.09)\end{array}$ & $\begin{array}{l}-6.258^{* * *} \\
(-13.70)\end{array}$ & -0.074 \\
\hline $100-500$ & $\begin{array}{l}-10.033^{* * *} \\
(-18.66)\end{array}$ & $\begin{array}{l}-8.974^{* * *} \\
(-21.82)\end{array}$ & 1.059 \\
\hline More than 500 & $\begin{array}{l}-16.154^{* * *} \\
(-26.05)\end{array}$ & $\begin{array}{l}-13.694^{* * *} \\
(-27.79)\end{array}$ & 2.460 \\
\hline \multicolumn{4}{|l|}{ Firm age (Reference: less than 5 years) } \\
\hline $5-10$ years & $\begin{array}{l}-5.218^{* * *} \\
(-11.00)\end{array}$ & $\begin{array}{l}-5.042^{* * *} \\
(-14.71)\end{array}$ & 0.176 \\
\hline $10-20$ years & $\begin{array}{l}-6.922^{* * *} \\
(-13.20)\end{array}$ & $\begin{array}{l}-7.917^{* * *} \\
(-21.85)\end{array}$ & -0.995 \\
\hline More than 20 years & $\begin{array}{l}-7.833^{* * *} \\
(-14.89)\end{array}$ & $\begin{array}{l}-9.148^{* * *} \\
(-20.43)\end{array}$ & -1.315 \\
\hline \multicolumn{4}{|l|}{$\begin{array}{l}\text { Main part of paid-in capital (Ref.: Hong Kong SAR, China, } \\
\text { Macao SAR, China, and Taiwan, China, capital) }\end{array}$} \\
\hline State capital & $\begin{array}{l}2.352^{* * *} \\
(4.42)\end{array}$ & $\begin{array}{l}2.574^{* * *} \\
(5.03)\end{array}$ & 0.222 \\
\hline Collective capital & $\begin{array}{l}1.631^{* * *} \\
(3.25)\end{array}$ & $\begin{array}{l}1.879^{* * *} \\
(3.83)\end{array}$ & 0.248 \\
\hline Corporate capital & $\begin{array}{l}1.159^{* *} \\
(2.29)\end{array}$ & $\begin{array}{l}2.789^{* * *} \\
(7.23)\end{array}$ & 1.630 \\
\hline Private capital & $\begin{array}{l}-0.323 \\
(-0.67)\end{array}$ & $\begin{array}{r}0.167 \\
(0.47)\end{array}$ & 0.490 \\
\hline Foreign capital & $\begin{array}{l}-3.555^{* * *} \\
(-5.98)\end{array}$ & $\begin{array}{l}-2.060^{* * *} \\
(-4.54)\end{array}$ & 1.495 \\
\hline Ratio of long-term investment to output value & $\begin{array}{l}0.057^{* * *} \\
(7.80)\end{array}$ & $\begin{array}{l}0.012^{*} \\
(1.68)\end{array}$ & -0.045 \\
\hline Ratio of intangible assets to output value & $\begin{array}{c}0.011 \\
(1.38)\end{array}$ & $\begin{array}{r}0.002 \\
(0.33)\end{array}$ & -0.009 \\
\hline Ratio of export delivery value to sales total output value & $\begin{array}{l}0.023^{* * *} \\
(4.49)\end{array}$ & $\begin{array}{l}-0.004 \\
(-1.08)\end{array}$ & -0.027 \\
\hline Ratio of new product to output value & $\begin{array}{l}-2.320^{*} \\
(-1.94)\end{array}$ & $\begin{array}{l}-5.277^{* * *} \\
(-6.99)\end{array}$ & -2.957 \\
\hline Ratio of labor, unemployment insurance to output value & $\begin{array}{l}-1.274^{* * *} \\
(-4.17)\end{array}$ & $\begin{array}{l}-0.368 \\
(-0.98)\end{array}$ & 0.906 \\
\hline Ratio of medical and retirement insurance to output value & $\begin{array}{l}0.292^{* * *} \\
(6.59)\end{array}$ & $\begin{array}{l}-0.116 \\
(-1.63)\end{array}$ & -0.408 \\
\hline Coastal province & $\begin{array}{l}-2.947^{* * *} \\
(-7.91)\end{array}$ & $\begin{array}{l}-4.261^{* * *} \\
(-13.83)\end{array}$ & -1.314 \\
\hline Constant & $\begin{array}{l}59.093^{* * *} \\
(77.37)\end{array}$ & $\begin{array}{l}59.160^{* * *} \\
(97.77)\end{array}$ & 0.067 \\
\hline $\mathrm{R}^{2}$ & 0.027 & 0.027 & \\
\hline Number of observations & 49146 & 78182 & \\
\hline
\end{tabular}

Note: t-statistics in parentheses. ${ }^{* * *}$ significant at $1 \% ;{ }^{* *}$ significant at $5 \% ;{ }^{*}$ significant at $10 \%$. 
Before the reforms in the late 1970s, the Chinese economy was dominated by state-owned enterprises and collective enterprises. The economic reforms have greatly reduced the share of state-owned enterprises and led to a coexistence of various types of enterprises. Non-state-owned enterprises, such as private enterprises, joint ventures and enterprises with foreign investment, have shown an extraordinary dynamism. In the present study, we use main part of paid-in capital as a proxy of firm ownership. We take the firms with the main part of paid-in capital from Hong Kong SAR, China, Macao SAR, China, and Taiwan, China, as the reference group, because their share in the total remained relatively stable in 2001-2005. The results show that firms with state capital, collective capital or corporate capital are more volatile, and their positive effect on productivity volatility is enhanced from 2001 to 2005, especially for corporate capital (Table 4 and Figure 4). On the contrary, foreign capital plays a role in reducing productivity volatility.

Figure 4.

Effect of main part of paid-in capital on productivity volatility

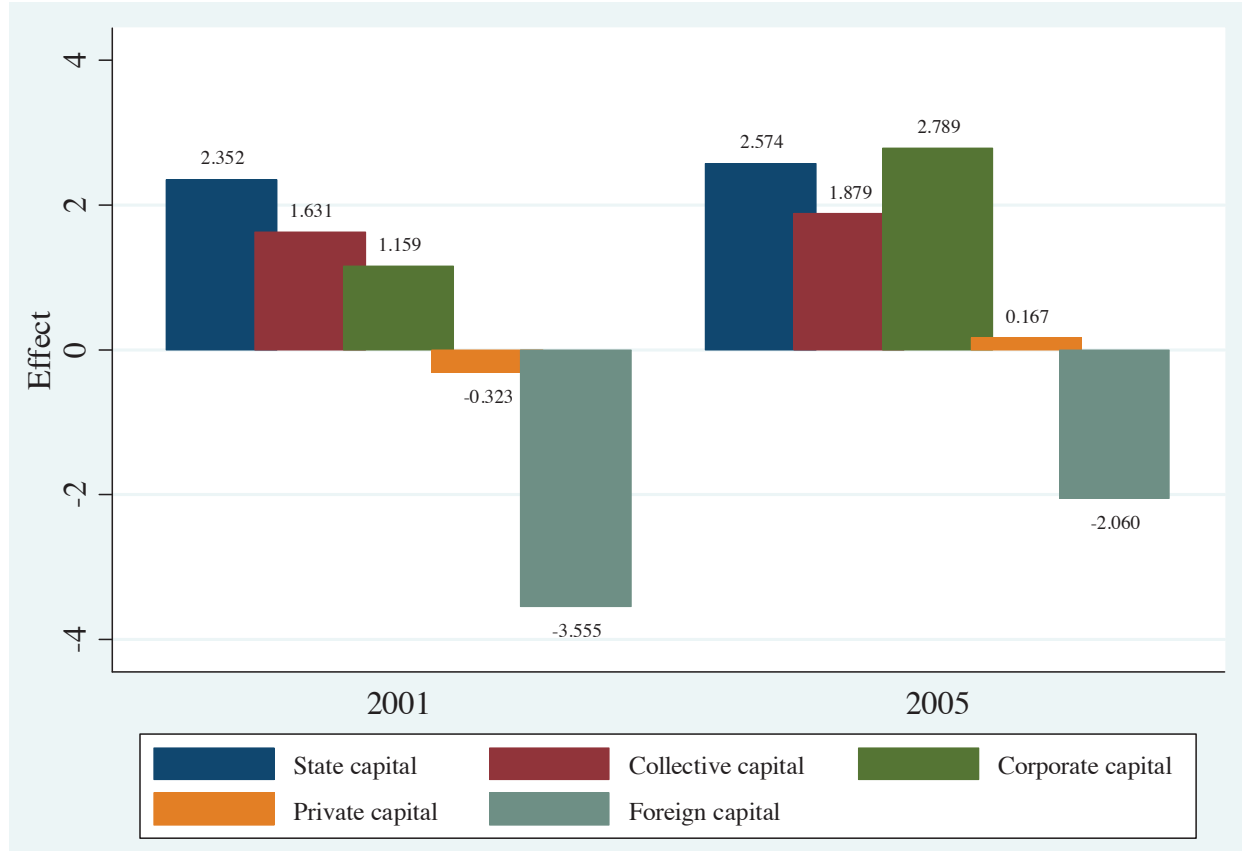

Reference: Hong Kong SAR, China, Macao SAR, China, \& Taiwan, China, capital.

The coefficients of long-term investment and export are significant in a positive way for the 2001 sample, but not significant for the 2005 sample. The ratio of new product to output value has a negative effect on productivity volatility, and this effect became much stronger from 2001 to 2005. The ratio of labor unemployment insurance to total output value is used as a proxy of the insurance that workers could have during job transitions. Its coefficient is significantly negative for the 2001 sample, but not significant for the 2005 sample, which raises an interesting question for further research. On the contrary, the ratio of medical and retirement insurance to total output value seems to enhance the productivity volatility for the 2001 sample, however, this effect is not significant for the 2005 sample. This result could be explained by the reforms of social security system. Previously, medical insurance and retirement pension were mainly the responsibility of firms, especially for state-owned firms. This expense was a heavy burden for firms that were in deficit or facing negative shocks and for old firms with many retirees. As the economic reforms deepened, the burdens on firms were alleviated in two ways, on the one hand, the share of non-state-owned firms, which do not always provide the benefits that stateowned firms provide, has sharply increased and, on the other hand, the social security system, including unemployment insurance, medical insurance and pensions, has gradually established. 
Both contributed to reducing the effect of medical and retirement insurance on the increase in firm productivity volatility.

Finally, we note the important effect of location in coastal provinces on reducing productivity volatility at the firm level. ${ }^{8}$ This effect is greatly enhanced from 2001 to 2005 . This is likely related to the vibrant business environment in the coast. Although firms compete for inputs and markets, they themselves, and the market thickness and deepness they created in the coast through clustering and agglomeration, reduce some idiosyncratic risks (such as shortage of supply of a specific input) and increase the diversity of markets. As observed, the joint forces reduce the productivity volatility of firms in coastal provinces.

The Oaxaca decomposition confirms that both the main effect and year effect play a role in the evolution in volatility (Table 5). One-third and two-thirds of volatility reduction are explained by the main effect and year effect, respectively.

Table 5.

Decomposition of the changes in productivity volatility (2001-2005)

\begin{tabular}{lcc}
\hline \hline & $\begin{array}{c}\text { Main effect } \\
\left(\hat{\beta}^{01} \cdot \Delta \bar{X}\right)\end{array}$ & $\begin{array}{c}\text { Year effect } \\
\left(\Delta \hat{\beta} \cdot \bar{X}_{05}\right)\end{array}$ \\
\hline Total & -0.292 & -0.561 \\
\hline Firm size (Reference: less than 50) & -0.171 & -0.015 \\
$\quad$ 50-100 & 0.044 & 0.548 \\
$\quad$ 100-500 & 0.419 & 0.416 \\
$\quad$ More than 500 & & \\
\hline Firm age (Reference: less than 5 years) & -0.116 & 0.063 \\
$\quad$ 5-10 years & -0.606 & -0.290 \\
$\quad$ 10-20 years & 1.074 & -0.200 \\
$\quad$ More than 20 years & & \\
\hline Main part of paid-in capital (Ref.: Hong Kong SAR, China, Macao SAR, & \\
China, and Taiwan, China, capital) & -0.396 & 0.021 \\
$\quad$ State capital & -0.189 & 0.022 \\
$\quad$ Collective capital & 0.075 & 0.385 \\
$\quad$ Corporate capital & -0.060 & 0.198 \\
$\quad$ Private capital & -0.054 & 0.157 \\
$\quad$ Foreign capital & -0.081 & -0.140 \\
\hline Ratio of long-term investment to output value & -0.002 & -0.038 \\
Ratio of intangible assets to output value & 0.079 & -0.590 \\
Ratio export delivery value to sales total output value & -0.026 & -0.127 \\
Ratio of new product to output value & 0.048 & 0.078 \\
Ratio of labor, unemployment insurance to output value \\
Ratio of medical and retirement insurance to output value \\
Coastal province & -0.160 & -0.104 \\
Constant & -0.171 & -1.012 \\
\hline \hline & & 0.067 \\
\hline
\end{tabular}

8 Firms in the coast and those in the inland might be different in sector, which can also drive the difference in productivity volatility. We plan to investigate this in another research. 
Figure 5 summarizes the contribution of various factors to the change in productivity volatility over time. Firm size is the major factor that increases productivity volatility over time - which has large positive main effect and year effect; while location is the major factor that reduces productivity volatility, which has large negative main effects and year effects. Other factors, such as firm age, capital and export ratios, also play a role, but their net effects are small as their main effects and year effects are in different directions and partially cancel out each other.

\section{Figure 5.}

Contribution of various factors to the change in productivity volatility

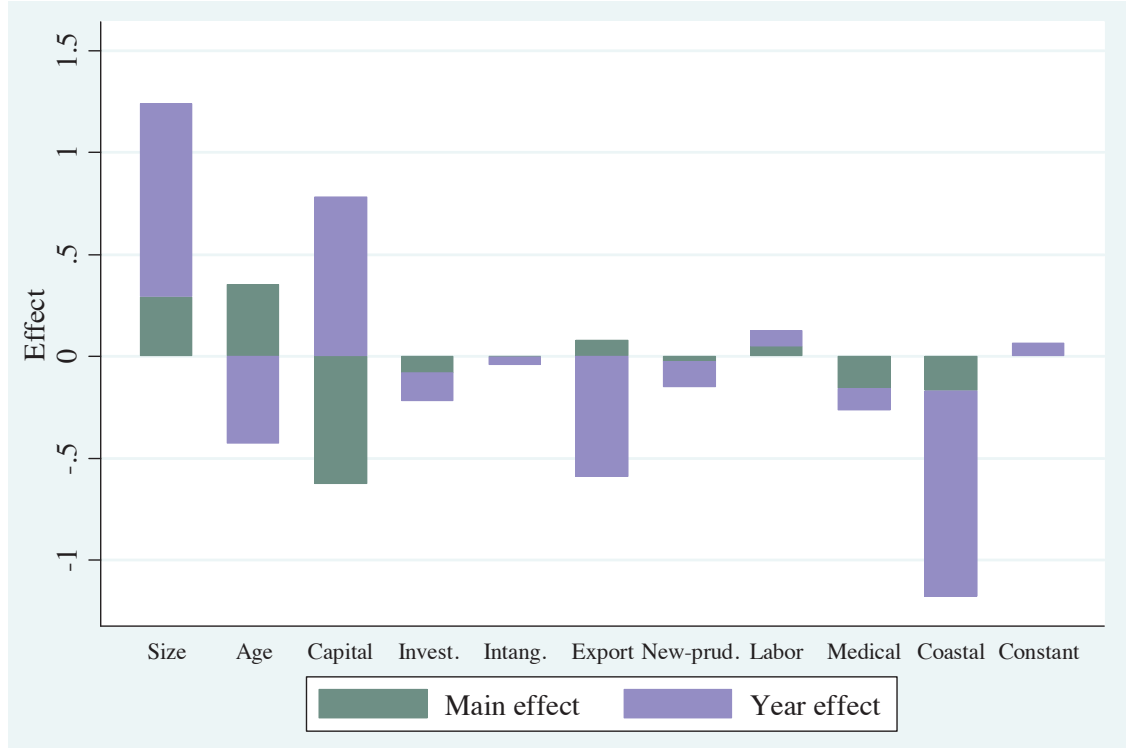

Note: Invest. = Long-term investment; Intang. = Intangible assets; New-prud. = New product; Labor = labor, unemployment insurance; Medical $=$ Medical and retirement insurance

Figure 6 illustrates the role of firm size in the changes in volatility. We observe that the positive main effect of firm size results essentially from the reduction of the number of large firms with more than 500 workers. The positive year effect is mainly due to the weakening of the effect of the medium (100-500) and large (more than 500) firms on reducing productivity volatility from 2001 and 2005.

\section{Figure 6.}

Contribution of firm size to the changes in productivity volatility

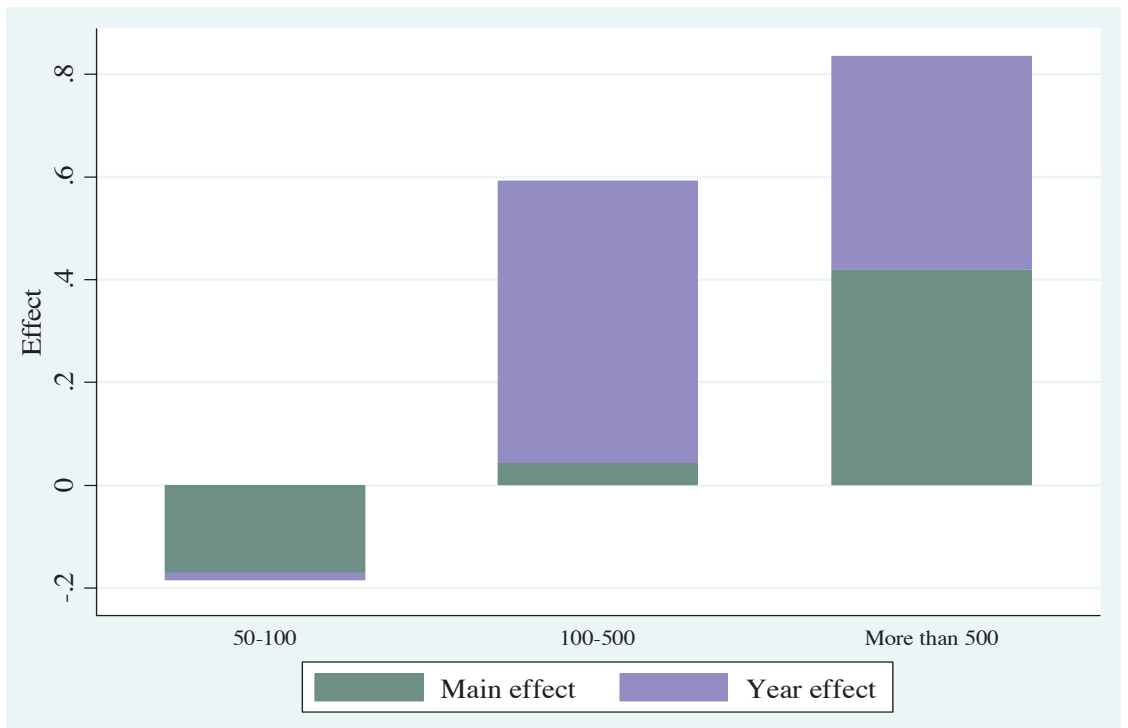


Firm's age has a positive main effect but a negative year effect on volatility change. Its positive main effect is essentially due to the decline of the number of old firms whose productivity is less volatile (Tables 1, 3 and Figure 7).

\section{Figure 7.}

Contribution of firm age to the changes in productivity volatility

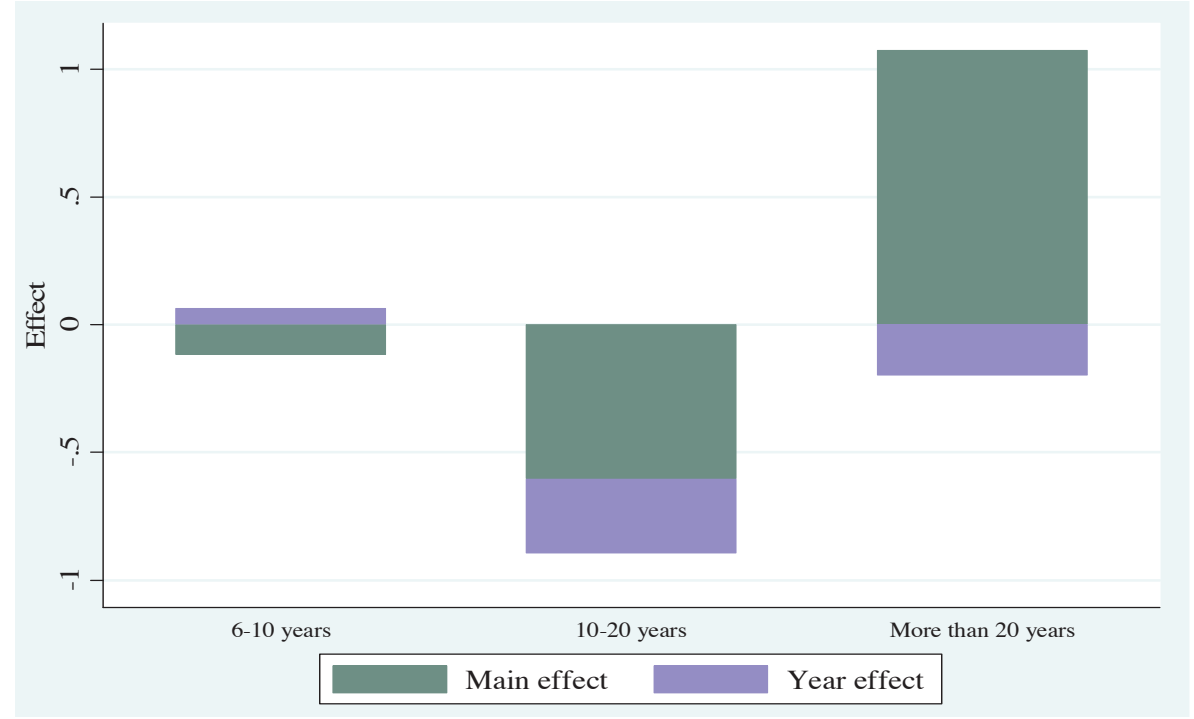

Reference: Less than 5 years.

The source of paid-in capital has a negative main effect and a positive year effect on volatility change (Figure 5). Figure 8 shows that the negative main effect results essentially from the reduction of the shares of state-owned firms and collective firms, which are generally more volatile in the period of this study (see Tables 1 and 3); whereas the positive year effect is due to the strengthening of the effect of firms with corporate capital on enhancing productivity volatility and the weakening of the effect of firms with foreign capital in reducing productivity volatility (see Table 4).

\section{Figure 8.}

Contribution of firm ownership to the changes in firm's productivity volatility

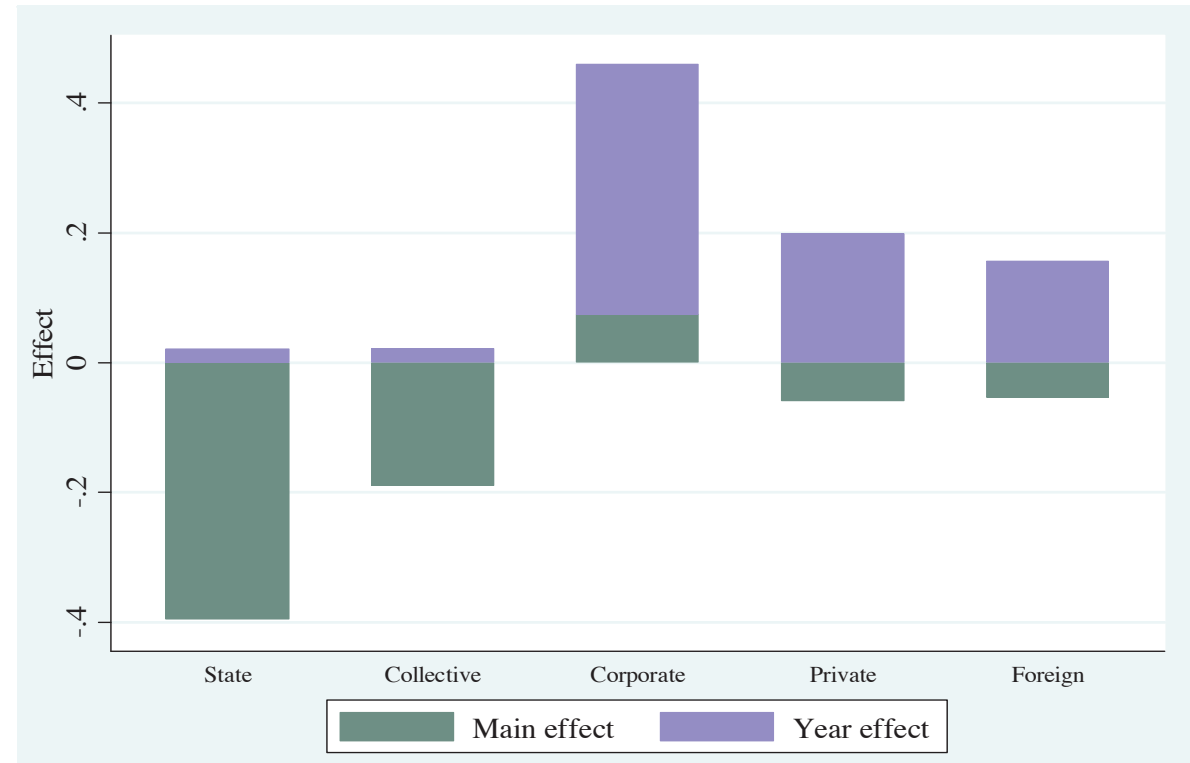

Reference: Hong Kong SAR, China, Macao SAR, China, \& Taiwan, China, capital. 
As we have seen above (Table 4), the ratio of export delivery value to total output value has a positive effect on volatility in 2001; but the effect is not significant in 2005. That leads to a negative year effect, reducing productivity volatility.

Finally, the share of firms located in coastal provinces, that are less volatile, increased from 2001 to 2005 (Table 3), which results in a negative main effect. On the other hand, the effect of coastal region on reducing productivity volatility also increased from 2001 to 2005 (Table 4), which leads to a large negative year effect. Because of the two negative effects, the growth of firms located in the coastal provinces plays the most important role in reducing productivity volatility.

\section{CONCLUSIONS}

In this paper, we described the level and changes in firm level productivity volatility in China and examined their driving forces. In general, productivity volatility declined over time in 2001-2005. Among firms of different characteristics, large firms, old firms, foreign firms, and firms located in the coastal provinces are less volatile. Firm size and location are the two major factors that drive changes in productivity volatility - one positively and one negatively. While the gaps of volatility between small firms and large firms declined, the gaps between firms located in the coastal provinces and inland provinces increased.

Two findings might be of interest of further research and contribute to policy design:

- The first one is related to the role in productivity volatility of the ratio of firms' contribution to medical insurance and retirement pension to total output value. It has a significant effect in increasing productivity volatility at the beginning of the period of study while the effect became insignificant at the later stage. This might indicate that, with the deepening of the enterprise reforms, healthcare reforms, and pension reforms, the alleviation of the undue burdens that firms used to bear helped reduce firm level productivity volatility by lowering their pressure particularly in downturn.

- The second one is related to the role of firms' location. Firms in coastal provinces were less volatile than those in inland provinces, and the gap widened over time. This might suggest, the negative effects on firm productivity volatility (which means reducing volatility) of a more enabling business environment in the coast dominate the positive effect of competition (which means increasing volatility).

It is to note that, a higher volatility at the individual firm level should not be considered as unfavorable as it might well represent efficient resources reallocation (or creative destruction). However, the above findings offer some support to the argument that a more inclusive social protection system can not only protect the vulnerable but also provide more space for firms to perform; and a better business environment is not only good for productivity growth but also for resilience.

\section{Acknowledgment}

This paper was prepared as a background paper of the World Development Report 2014: Risk and Opportunity. The findings, interpretations, and conclusions expressed in this paper are entirely those of the authors. They do not necessarily represent the views of their affiliated organizations. The authors would like to thank Sandra Poncet for sharing the data, Jean-Jacques Dethier, Russell Pittman, Yanrui Wu, and participants at the ninth International Conference on the Chinese Economy, CERDI-IDREC, University of Auvergne, France (October 2013) for valuable comments. 


\section{References}

Bari, Dominique (1997), Chine: la grande mutation, Paris: Editions sociales.

Baxter, Marianne \& Robert King (1999), "Measuring Business Cycles: Approximate Band-Pass Filters for Economic Time Series", Review of Economics and Statistics, 81(4), pp. 575-593.

Blinder, Alan S. (1973), "Wage Discrimination: Reduced Form and Structural Estimates", The Journal of Human Resources, 8(4), pp. 436-455.

Brandt, Loren, Johannes Van Biesebroeck \& Yifan Zhang (2009), "Creative Accounting or Creative Destruction? Firm Level Productivity Growth in Chinese Manufacturing”, NBER Working Paper Series, No. 15152.

Breen, Richard \& Cecilia García-Peñalosa (2005), "Income Inequality and Macroeconomic Volatility: An Empirical Investigation", Review of Development Economics, 9(3), pp. 380-398.

Comin, Diego \& Sunil Mulani (2005), "A Theory of Growth and Volatility at the Aggregate and Firm Level”, NBER Working Paper Series, No. 12354.

Comin, Diego \& Thomas Philippon (2005), The Rise in Firm-Level Volatility: Causes and Consequences, NBER Working Paper Series, No. 11388.

Cunat, Alejandro \& Marc J. Melitz (2007), "Volatility, Labor Market Flexibility, and the Pattern of Comparative Advantage", NBER Working Paper Series, No. 13062.

Davis, Steven J., John Haltiwanger, Ron Jarmin \& Javier Miranda (2006), "Volatility and Dispersion in Business Growth Rates: Publicly Traded versus Privately Held Firms", NBER Working Paper Series, No. 12354.

de Beer, Patrice \& Rocca Jean-Louis (1997), La Chine à la fin de l'ère DENG Xiaoping, Paris: Le Monde-Editions. de Veirman, Emmanuel \& Andrew Levin (2009), "Measuring Changes in Firm-Level Volatility: An Application to Japan", Reserve Bank of New Zealand, Discussion paper, DP2009/20.

Hausmann, Ricardo \& Michael Gavin (1996), "Securing Stability and Growth in a Shock Prone Region: The Policy Challenges for Latin America", Inter-American Development Bank, Office of the Chief Economist, Working Paper 315, January 1996, Washington, D.C.

Jefferson, Gary H., Thomas G. Rawski \& Yifan Zhang (2008), "Productivity Growth and Convergence across China's Industrial Economy", Journal of Chinese Economic and Business Studies, 6(2), p. 121-140.

Loayza, Norman V. \& Luis Servén (2010), Business Regulation and Economic Performance, The World Bank, Washington, D.C.

Loayza, Norman V., Romain Rancière, Luis Servén \& Jaume Ventura (2007), "Macroeconomic Volatility and Welfare in Developing Countries", World Bank Economic Review, 21, https://openknowledge.worldbank. org/handle/10986/4461.

Oaxaca, Ronald (1973), "Male-Female Wage Differentials in Urban Labor Markets", International Economic Review, 14(3), pp. 693-709.

Putterman, Louis (1992), "Dualism and Reforme in China", Economic Developpement and Cultural Change, 40(3), pp. 467-493.

Smith, James P. \& Finis R. Welch (1989), "Black Economic Progress After Myrdal”, Journal of Economic Literature, 27(2), pp. 529-564.

The World Bank (2007), China's Modernizing Labor Market: Trends and Emerging Challenges, The World Bank, Washington DC.

Wei, Yingqi \& Xiaming Liu (2006), "Productivity spillovers from R\&D, exports and FDI in China's manufacturing sector", Journal of International Business Studies, 37(4), pp. 544-557. 